NBER WORKING PAPER SERIES

\title{
HEALTH AND NUTRITION IN THE PREINDUSTRIAL ERA: INSIGHTS FROM A MILLENNIUM OF AVERAGE HEIGHTS IN NORTHERN EUROPE
}

\author{
Richard H. Steckel \\ Working Paper 8542 \\ http://www.nber.org/papers/w8542 \\ NATIONAL BUREAU OF ECONOMIC RESEARCH \\ 1050 Massachusetts Avenue \\ Cambridge, MA 02138 \\ October 2001
}

A revised version of a paper prepared for the conference on New Evidence on the Standard of Living in Preindustrial Europe and Asia, which was held in Arild, Sweden, August 1-5, 2000. The author thanks Robert Allen, Tommy Bengtsson, and members of the Chicago Area Economic History Seminar for comments and suggestions. The views expressed herein are those of the author and not necessarily those of the National Bureau of Economic Research.

(C) 2001 by Richard H. Steckel. All rights reserved. Short sections of text, not to exceed two paragraphs, may be quoted without explicit permission provided that full credit, including $\mathbb{C}$ notice, is given to the source. 
Health and Nutrition in the Preindustrial Era:

Insights from a Millennium of Average Heights in Northern Europe

Richard H. Steckel

NBER Working Paper No. 8542

October 2001

JEL No. N3, I1, J1

\begin{abstract}
This essay places the debate over human welfare during industrialization in the context of very long-term economic developments by examining an important aspect of living standards--health and nutrition--since the Middle Ages. I use average stature determined from military records along with a neglected source, skeletal data. Average heights fell from an average of 173.4 centimeters in the early Middle Ages to a low of 165.8 centimeters during the seventeenth and eighteenth centuries. This decline of 7.6 centimeters exceeds by a factor of two any downturns found during industrialization in several countries that have been studied. Moreover, recovery to levels achieved in the early Middle Ages was not attained until the early twentieth century. The paper links the decline in average height to climate deterioration; growing inequality; urbanization and the expansion of trade and commerce, which facilitated the spread of diseases; the global spread of diseases associated with European expansion and colonization; and conflicts or wars over state building or religion. Because it is reasonable to believe that greater exposure to pathogens accompanied urbanization and industrialization, and there is evidence of climate moderation, increasing efficiency in agriculture and greater inter-regional and international trade in foodstuffs, it is plausible to link height gains that began in the eighteenth century with dietary improvements.
\end{abstract}

Richard H. Steckel

Economics Department

Ohio State University

Columbus, $\mathrm{OH} 43210$

and NBER

Steckel.1@osu.edu 
For over half a century, quantitative economic historians have pondered the fates of workers and other segments the population during the industrial revolutions of the nineteenth and early twentieth centuries. While everyone agrees that the standard of living eventually improved, much discussion has focused on how various groups fared during the decades that industrialization actually unfolded. Scholars of the subject have asked who gained and who lost in the process (and why), and whether industrialization was accompanied by events that adversely affected health and human welfare. In the case of England, debate has been particularly lively and factions have coalesced into camps of optimists and pessimists. Controversy persists because evidence about the past is often meager and, in any event, health and human welfare are complex and difficult to assess under the best circumstances of data availability (for a discussion of issues, see Engerman, 1997).

This paper places the debate over human welfare during industrialization in the context of very long-term economic developments by examining an important aspect of living standards--health and nutrition--since the Middle Ages. I use average stature determined from military records along with a neglected source, skeletal data. ${ }^{1}$ Considering the industrial period as a backdrop for comparative study, I describe the Ushape that average heights took over the past millennium in northern Europe and suggest a research agenda for analyzing this remarkable time trend in health and nutrition. ${ }^{2}$

\section{Background}

\footnotetext{
${ }^{1}$ Average heights calculated from skeletal data have long been used by physical anthropologists but little used by other social scientists. For a study of England oriented toward medical historians, see Stephen Kunitz (1987).
} 
Although lacking survey results on the subject, I suspect that few scholars would challenge whether the substantial resources allocated to the standard of living debate have been worthwhile investments as a whole. No doubt, many would object to some books or papers, but all would recognize that industrialization has been the biggest news of the past two centuries on the economic front. Unquestionably, industrialization transformed social and economic life, and even poor groups within modern industrial countries have greater access to most types of material goods and live longer lives than the upper classes in the pre-industrial era. Study of industrialization is also warranted for insights that may help guide developing countries now undergoing the process.

Considerable devotion to the subject of welfare during industrialization is justified, but the neglect of the preindustrial era is curious. The lack of attention cannot be explained by a supposition that industrialization was the only major dynamic feature of social and economic life over the past several millennia. Earlier transformations were arguably on par if not more significant, including the shift from foraging to farming, the rise of cities, and European expansion and colonization that began in the 1400s.

The neglect might be explained by temporal distance from the present, a forceful point among those scholars who believe that modern policy implications should flow from the work of most if not all economists, including economic historians. People of this persuasion may ask what could possibly be learned about problems in the modern world by studying the preindustrial era. In reply, one might observe that the preindustrial world of the past is relevant because parts of today's developing regions approximate preindustrial conditions of the eighteenth or nineteenth centuries. More importantly,

\footnotetext{
${ }^{2}$ Readers unfamiliar with the methodology of anthropometric history may want to consult the discussion and references in Steckel (1995).
} 
study of preindustrial economies is justifiable as a form of basic research. All social scientists understand the value of large, diverse samples for generalizing about human behavior, and the past is certainly diverse. In any event, economic historians, and historians, are seldom beholden to arguments that research must demonstrate immediate applications. Many are content in viewing research purely as consumption, or satisfying desires of intellectual curiosity.

On a practical level, data availability is a problem, at least for the type of monetary measures that economists are accustomed to using, such as real GDP, real wages, or wealth. While it is certainly not true that abundant data exist for the taking, it is also not true that evidence is completely lacking. Over the years I have been impressed by the ingenuity of historians and economists in developing new data resources, a record that leads one to doubt whether most useful sources have been exploited. Recently, the frontiers of research were extended backward in time and over space, at least in the dimension of wages and prices (Allen, 1998).

Finally, new data sources and methods have been developed for assessing human welfare. Speaking metaphorically, one may think of the history of human welfare in a country or region as a long sausage or salami; each slice represents a year (or other time unit) of social performance that can be divided into broad categories of health, material goods, and psychological elements, which may have spiritual or metaphysical components. The example of the new anthropometric history shows that a significant portion of the health component is measurable from military records and other sources of height data (Steckel, 1998). Skeletal evidence greatly extends backward in time the portion of the salami that is visible, broadens it to include women and children, and 
unlike stature alone, includes information on degenerative health processes associated with hard work and aging. This paper makes a small down payment on the larger research agenda of integrating the analysis of preindustrial height data from skeletal records and military sources into the literature of economic history.

\section{Height patterns during industrialization}

Before attempting to study human health and nutrition in preindustrial times, it is necessary to determine when the industrial period began. Although some scholars debate whether "revolution" should be appended to "industrial" in describing the process, the changes were revolutionary from the perspective of several centuries of history. Because it was a complex phenomenon involving many dimensions of change that occurred at different rates in various countries, its chronological dates are inevitably fuzzy. Rostow's stages of economic growth are now viewed as inordinately rigid, but economic historians agree that England was the first industrial country and that the process spread from west to east across Europe. It is useful to identify various steps or stages of the general process based on the extent of mechanization, the rate of economic growth, percent of the labor force involved in agriculture, and the amount of technological change. In the early industrial period, the transition to a modern industrial economy began. Industrialization and modernization spread geographically and diversified in the middle period, and became widespread and dominant in the late industrial phase. Notably, a few countries do not fit the classical mold of industrial change. Because they retained large agricultural sectors or experienced little mechanization and developed few factories, the term "modernization" may be more appropriate in describing their experiences. Australia, for 
example, relied extensively on agriculture and mining, while the Netherlands (lacking coal and waterpower), developed banking, shipping, and services.

Table 1 depicts average heights and other information during early, middle and late stages of industrialization in 8 countries whose adult male heights were studied in Steckel and Floud (eds.), Health and Welfare during Industrialization. In examining the table, one is struck by the diversity of experience across countries in heights, and in life expectancy and the percent urban. Average heights varied by over 15 centimeters within each phase, while the percent urban differed by as much as 30 percentage points in the early phase (the Netherlands versus the United States) and nearly 50 points in the late phase (Japan versus Sweden). While all life expectancies were somewhat compressed in the preindustrial phase, differing by less than 13 years (Australia versus the UK), by the late phase Australia had leaped ahead of the pack (65.4 years) while Japan lagged nearly 20 years behind (47 years).

Height and life expectancy. In arguing for average height as a general welfare measure, it is useful to consider its relationship to a more widely employed measure of health--life expectancy at birth. The connection between average height and life expectancy in a historical setting is most reliably calculated for the late industrial period, when better estimates of life expectancy are available. Figure 1 shows the scatter diagram for the US, UK, the Netherlands, France, Sweden, Germany, Japan, and Australia. The estimated regression line is ( $t$-values in parentheses):

$$
\text { Height }=152.48+0.330\left(\text { Life Expectancy), } N=8, R^{2}=0.40\right.
$$


The average height of adult men increased by 0.33 centimeters for every year by which life expectancy increased. The scatter diagram reveals that Japan is a substantial outlier, and if this country is omitted, the $\mathrm{R}^{2}$ rises to 0.79 and the regression coefficient is statistically significant at 0.01 . Japan's stature was much too low, given its life expectancy, probably because the time frames of the two measures are different.

Conditions in the 1930s and early 1940s, when the young adults of mid-century were growing children, were likely worse than those forming the basis for life expectancy in 1950, a few years following the end of World War II. It is also possible that the heightlife expectancy relationship is somewhat non-linear at low levels of health.

Height and urbanization. Table 1 shows that average male height and per cent urban (towns or cities of 2,500 population or more) varied widely across the countries during the middle phase of industrialization, a period of intense change. With regard to stature, the extremes were established by the Australians $(172 \mathrm{~cm})$ and the Japanese, who fell more than $13 \mathrm{~cm}$ behind. In urban development, the Swedes had the smallest share living in towns or cities (only 17.2\%) while the Japanese were the most urban (60\%).

It was not accidental that the Japanese were both the shortest and the most urban. In an era before widespread, effective investments in public health and personal hygiene, the congestion and turnover associated with urban living increased the chances of exposure to pathogens. Other features detrimental to health are often found in cities, such as a large number of poor people who lacked access to food, clothing and shelter that would have increased resistance to disease. 
The scatter diagram in Figure 2 confirms the adverse effect of urbanization on health. The estimated regression equation is (t-values in parentheses):

$$
\text { Height }=174.07-0.153\left(\text { Per cent Urban), } N=8, R^{2}=0.27\right.
$$

For every percentage point increase in the degree of urbanization, average male height fell by about 0.15 centimeters. This magnitude is significant in a practical sense because the transition from a low (say, 20\%) level of urbanization to a moderately high level (say $50 \%$ ) would have decreased average height by 4.5 centimeters. The notable outlier to the inverse relationship was Australia, which had the tallest population and the second highest level of urbanization. If Australia is dropped from the regression, the t-value rises to $-2.60, \mathrm{R}^{2}$ increases to 0.57 , and the regression coefficient increases (in absolute value) by $50 \%$.

What factors explain the exceptional nature of health and urbanization in Australia? One was the relative geographic isolation of the country from major disease currents that affected cities in Europe and in North American. Another is the remoteness of the major cities within Australia from each other, which helped to reduce the spread of infectious disease. Moreover, Australia's industrialization (or modernization) occurred late enough to benefit from significant investments in public health. This last feature distinguishes Australia from Japan, which was also a late industrializer within this group.

Temporal patterns. Additional factors that influenced heights during

industrialization, and possibly in the preindustrial period, can be discerned from study of 
temporal patterns within countries. The patterns can be placed into three categories of (a) important declines in health during a large phase of industrialization; (b) sustained, but not necessarily monotonic, improvement; and (c) a mixture that featured a series of short cycles.

Figures 3 and 4 show that the US and the UK fit the first pattern. Americans were very tall by global standards in the early nineteenth century as a result of their rich and varied diets, low population density, and relative equality of wealth. Between 1830 and roughly 1880, however, the average height of American men fell by about 3 centimeters, a reversal that was not offset until the 1920s. Consistent with this height decline, life expectancies tabulated from genealogies also show a deterioration near the middle of the century (Pope 1992). Researchers in the field have suggested numerous possible causal factors for the decline, including the spread of disease affiliated with the development of railroads, canals, and steamboats (for discussions see Steckel, 1995 and Komlos, 1998). Also mentioned are higher food prices; growing inequality, the emergence of business cycles that led to malnutrition during contractions, urbanization, and the rise of public schools that exposed children to major diseases. Unfortunately, research has not advanced to the point of assigning plausible weights to these factors.

Although health deterioration also occurred in Britain during the early-mid nineteenth century, the timing is probably more coincidental than emblematic of similar causal factors at work. While it is possible that growing trade and commerce spread disease, as in the United States, it is more likely that a major culprit was rapid urbanization and associated increased in exposure to diseases (Floud and Harris, 1997). This conclusion is reached by noting that urban born men were substantially shorter than 
the rural born, and between the periods of 1800-1830 and 1830-1870 the share of the British population living in urban areas leaped from 38.7 to $54.1 \%$.

Sweden realized the most sustained increase in health during the most intense period of industrialization (late nineteenth century), but France, the Netherlands, and Japan also posted significant, if somewhat interrupted, gains. Figure 5 shows that average adult male heights in Sweden rose from 168 to 172.5 centimeters between 1860 and 1900. The only downturn was the small reversal that occurred during the crop failures of the late 1860s, which had little to do with industrialization (Sandberg and Steckel, 1997). Paralleling the growth in stature were declines in childhood mortality rates of roughly $50 \%$. It is notable that Sweden had the least urbanized population among the eight countries studied, and it also benefited from public health measures such as vaccination, and from relatively low food prices created by the spread of potato cultivation and imports of food from America.

Most noticeable in the Dutch experience (Figure 6) was the large pre-industrial height decline that was caused in part by rising food prices and stagnating nominal wages (i.e. a decline in purchasing power). This trend was not reversed until the conscription years of the late 1850s (birth years of the late 1830s). Thereafter, average heights increased more or less continuously into the twentieth century with the exception of the reversal and stagnation of those measured from the late 1880s through the late 1890s. The latter was associated with the income decline of the 1860s and the economic depression of the 1870s (Drukker and Tassenaar, 1997).

The French experience (Figure 7) of the late nineteenth century is similar to that of the Netherlands. On the eve of industrialization, both populations attained about 164 
centimeters and both realized slow and steady growth in heights with the exception of the slight reversal and stagnation for those measured in the last decade of the century. The steady advance in heights was accompanied by steady progress in economic measured such as GDP per capita and by life expectancy. Like the Netherlands, France also experienced a decline in economic conditions that affected average heights; a downturn in real wages in the early 1860 s was followed by a decade and a half of stagnation (Weir, 1997).

Figure 8 shows that Japan opened the industrial era at the turn of the twentieth century with the smallest stature (about 157 centimeters) of any industrializing country. Hampered by a low protein diet, thereafter progress was slow and significantly correlated with per capita GDP but adversely affected by economic policy that diverted resources to the military (Honda, 1997). Its high level of urbanization and modest investments in public health were obstacles to human health and physical growth. Economic stagnation in the 1920s and the depression of the 1930s (which was rather mild in Japan) brought the modest gains in height to a halt in the mid 1930s.

Germany (Figure 9) realized gains in health during industrialization, but progress was choppy, or otherwise interrupted by relatively brief cycles in height (Twarog, 1997). Adult males reached about 163.5 centimeters (average of rural and urban) in the province of Württemberg on the eve of industrialization, which began in the 1860s. A small spurt in average heights occurred during the 1870 s, followed by decline and stagnation in the 1880s. This temporal pattern was related to the financial crash of 1873 and the subsequent depression that lasted into the early 1890s. Occupational differences in stature indicate that the professional classes were protected during the early phases of the 
economic depression and the loss in health was concentrated among the middle and lower classes. Thus, growing inequality played an important role in Germany's health trends during industrialization.

Figure 10 shows two features distinguish the Australian experience: the tall stature (about 172.5 centimeters) on the eve of modernization that was followed by a large cycle in heights whereby the average height of the mid 1870s was not attained again until the second decade of the twentieth century (Whitwell et. al., 1997). The tall stature is undoubtedly related to an inexpensive but diverse diet that was also rich in protein, a phenomenon supporting the view that Australia was a workingman's paradise. Even though the share living in urban areas was relatively high (about 50\%), overall population density was low and the country and its major cities were relatively isolated, which hampered the spread of communicable diseases.

But some troubles occurred even in these relatively idyllic circumstances. The height downturn of the 1880s and 1980s was the result of a double whammy. The share living in urban areas was already high (43\% in 1881) and then jumped eight percentage points in the decade following. A sanitary crisis followed and typhoid fever, which disproportionately affected the young, was epidemic in the cities. Although the pace of urbanization fell considerably during the 1890s, GDP declined and remained relatively low for a decade, thereby dampening any hopes for quick recovery in heights and health.

Generalizations. Study of height and mortality patterns in counties diverse by time period of industrialization and by environmental factors indicates that a combination of general tendencies and idiosyncratic factors affected health during the industrial revolutions of the nineteenth and early twentieth centuries. In an era when public health 
policies were often lacking or meagerly enlightened by theories of disease causation, urbanization was a widespread culprit in ill health within countries studied in Europe and in the Pacific, and within the US. Height was inversely correlated with degree of urbanization across countries, and rising urbanization led to health deterioration, especially in England, Australia, and Japan.

Major business cycles also affected heights and health. France, the Netherlands, Germany, and Australia were victims of major downturns. Changing economic opportunities, in the form of growing inequality, adversely affected heights in Germany and the US.

Diets were important for health and human growth. Countries with the tallest men (Australia and the US) had excellent access to a variety of foods, including several rich sources of protein. Food was expensive and the diet was low in protein in the country with the smallest stature (Japan).

Lastly, public health policy (or lack thereof) was also important for heights. Countries that industrialized early, such as the US and the UK suffered the most, in part because the adverse effects of trade and population concentrations on health could not be offset by health policies informed by reliable theories of disease causation. Merely arriving late on the scene was no guarantee of protection against the byproducts of industrialization, however, as shown by the Japanese case where resources that could have been used for public health and human growth were diverted to the military. 


\section{Preindustrial heights}

Among the 8 countries studied in Health and Welfare during Industrialization, all but Germany have some military height data that cover small portions of the preindustrial era. In the absence of detailed information, economic historians may tend to view the preindustrial world as a vague but homogeneous lump defined by its heavy reliance on agriculture, the preponderance of home manufacturing, and antiquated methods of production. Table 1 shows, however, that on the eve of industrialization, average heights ranged widely from 155 centimeters in Japan to approximately 173 in the United States and Australia. Most European countries clustered near 164 or 165 centimeters, but the Swedes reached 168.

In all but the United States, the preindustrial populations were also smaller, often by several centimeters depending upon the exact years of the comparisons. Considering the preindustrial and middle phase, for example, the height differences shown in Table 1 were about 2 centimeters in France, roughly 4 centimeters in Japan, the Netherlands and Sweden, and about 5 centimeters in Britain (but note that average heights declined significantly in Britain for cohorts born in the 1840s and early 1850s). Average heights in the US were about 3 centimeters lower in the middle compared with preindustrial times.

What were the important socioeconomic conditions affecting preindustrial heights? It would seem appropriate to begin with mechanisms that were powerful in explaining height differences during industrialization — urbanization and abundant access to land. The two countries with the tallest people (Australia and the US) score well on 
the latter category, and Sweden was the tallest and least congested of the European countries. Access to land tended to ameliorated poverty, helped promote dietary diversity and reduced the spread of disease by lowering population density. Countries with the shortest populations were relatively urban, a feature long known to have impaired health. Australians were tall despite a large (30\%) urban population, likely because the cities were isolated from each other and from much of the rest of the world.

If low urbanization and low population density were good for health, it is a fair question to ask why so many of the preindustrial populations were so short, compared with their industrial counterparts. After all, the adverse factors of urbanization and population density tended to increase with industrialization. With the exception of the US and Britain in the late industrial phase, there must have been something good for health about industrialization that more than offset the features that were bad.

Extending the Record. Before attempting to generalize, or even beginning to formulate a research agenda on the possible causes of small stature in the preindustrial era, it is essential to inspect additional evidence. Figures 3-10 make clear that the time span available for study of preindustrial heights from military records is rather short (or nonexistent) in all countries. ${ }^{3}$ Skeletal data, in which stature is inferred from long bone (femur) lengths, provide some information on the more distant past. ${ }^{4}$ Before examining the results, it is worth noting that biases of unknown magnitudes can affect average heights calculated from skeletal data. The excavated burials may not reflect the once-

\footnotetext{
${ }^{3}$ Some $17^{\text {th }}$ century military records in France contain measurements of soldiers, which are useful for studying pre-industrial trends in heights. Komlos, Hau and Bourguinat (2001) report an upward trend (with moderate fluctuations) in average height for birth cohorts of the late $17^{\text {th }}$ century to the mid $18^{\text {th }}$ century. Further search efforts might reveal additional preindustrial height records for other countries.

${ }^{4}$ On average, approximately 26 per cent of a person's height is contained in the thigh, as expressed in the femur bone. The most widely used formula for converting femur length into height was developed by Trotter and Gleser (1952).
} 
living population if burials were geographically dispersed, excavation was incomplete or quality of preservation of the bones was poor. Therefore, in this line of work it will be useful to compare results from a particular site with those from sites where these problems are thought to be minimal.

Table 2 gives details from individual studies found in a search of the literature in physical anthropology from sources easily accessible in the United States. Although some results were available for other parts of Europe, only northern Europe had studies that span the entire period from the early Middle Ages to the present. My first effort leaves a gap for the $15^{\text {th }}$ and $16^{\text {th }}$ centuries, which additional search may fill.

Table 3 summarizes results by era for those studies that give evidence for time periods as small as two or three centuries. Studies reporting results for burials during "Medieval Era" or the "Middle Ages" are lumped together in the middle of the table. It is remarkable if not stunning that the average heights during the early and late Middle Ages exceeded those observed for the eve of industrialization by several centimeters. While one should always devote some attention to the issues of representativeness and sampling in skeletal data, the large number of studies covering several northern countries suggests that the results cannot be dismissed as a statistical fluke or aberration. It is conceivable that all of the estimated heights for the Middle Ages were biased upward by some as yet undiscovered process of selection, but one would then wonder why that selection process ceased to be a factor in the centuries immediately prior to industrialization.

Generalizing about pre-industrial height trends will be difficult without more evidence for the $15^{\text {th }}$ through the $18^{\text {th }}$ centuries. It seems reasonable to suggest, at least tentatively, that net nutritional conditions of the past millennium reached a low point in 
Europe prior to the onset of industrialization. Between the Middle Ages and the twentieth century, heights were U-shaped with a minimum attained sometime between 1450 and 1750 , when historical heights become widely available from military records. The onset of the decline (and ultimately its causes) can be established only by a search for more evidence from published or unpublished sources. ${ }^{5}$

Taking the evidence at face value indicates that average heights fell from an average of 173.4 centimeters in the early Middle Ages to a low of 165.8 centimeters during the seventeenth and eighteenth centuries. This decline of 7.6 centimeters exceeds by a factor of two any fluctuations observed during industrialization. Recovery to levels achieved a millennium ago was not attained until the early twentieth century. Both the extraordinary level relative to recent times, and the U-shaped time trend are remarkable phenomena worthy of considerable study.

Some people may claim that genetic factors are responsible for the tall statures observed during the Middle Ages, pointing to the fact that northern Europeans are taller, even today, than those from more southern European countries (Schmidt, Jorgensen and Michaelsen, 1995). But the southern Europeans of the modern period, who tend to be poorer, are catching up, and in any event, studies of children around the globe indicate that children who grow up under similarly good environmental conditions have about the same heights (Malcolm, 1974; Martorell and Habicht, 1986). If genetic factors were relevant, presumably they had little or no effect on the trend within areas surrounded by

\footnotetext{
${ }^{5}$ Along with 3 co-investigators, I am planning a research project to undertake an extensive project that will collect and analyze data from skeletons covering the last 10 millennia in Europe. The effort will obtain not just heights (from femur lengths) but also information on degenerative joint disease, dental decay, anemia, and other skeletal indicators of chronic biological stress.
} 
the North Sea and the Baltic. Thus, I seek environmental explanations for northern Europe's U-shaped trend in stature.

In suggesting candidates for further study, it is relevant to recall that average height measures a population's history of net nutrition — diet minus claims on the diet made by work and by disease. Urbanization and growing population density, which occurred during industrialization, increased exposure to disease. Could the diet have been poorer and work more arduous in preindustrial times, by enough to offset the benefits of lower population density? And if the diet was poorer and work was more arduous, why was net nutrition so good before the sixteenth century?

The data at hand confront conventional wisdom about changes in living standards since the Middle Ages, and lead one to ask: Why did net nutrition decline sometime between the Middle Ages and the pre-industrial period? Why did heights generally improve during the nineteenth century, albeit with interruptions in some countries, when some factors adverse to heights (urbanization, inequality and business cycles) were getting worse?

As I do not have convincing answers to these questions, I look forward to additional research. It seems to me, however, that the millennium long U-shape of average stature in northern Europe might have been connected with six major phenomena: climate change, growing inequality in real incomes after 1500, urbanization and growth of trade that spread diseases, wars of state building, religious conflicts, and the global spread of new varieties of disease associated with European expansion and colonization. We are faced, then, not with a dearth of plausible explanations but rather 
measuring their impacts on health and weeding out influences among those that were unimportant.

Possible causes of good net nutrition during the Middle Ages. At the outset, it is useful to consider why average heights were surprisingly large during the Middle Ages. One might debate the representativeness of the results, something that is useful more generally of findings so at odds with preconceptions. Because numerous skeletal studies are essentially uniform in reporting statures in the Middle Ages that were tall by standards of the late nineteenth century, however, it seems prudent to accept them at face value (at least provisionally) and move to possible explanations. ${ }^{6}$

According to the data at hand, northern European heights did not consistently exceed those of 800-1300AD until the early twentieth century. One important factor in this remarkable may have been climate. Agriculture during the period from about 900 to 1300AD benefited from what climate historians call the "Medieval Warm Period" (see Figure 11). Based on ice cores, tree rings and other sources, climate historians believe that temperatures during this era were as much as 2-3 degrees (centigrade) warmer than a few centuries later, and 0.7 to 1.0 degrees above $20^{\text {th }}$ century averages (see Fagan, 2000). At the beginning of this era, the Vikings settled Iceland and later Greenland. This temperature change may not appear to be significant, but it was enough to extend the growing season by 3-4 weeks in many settled regions of northern Europe. The weather was sufficiently warm that commercial vineyards were viable 300 to 500 kilometers north of their range in the $20^{\text {th }}$ century. Moreover, it allowed cultivation of previously

\footnotetext{
${ }^{6}$ This is not the first time that anthropometric historians have found surprising if not startling results. The very small statures of slave children followed by remarkable catch-up growth, the American height decline during the mid-nineteenth century, and the very tall statures of the equestrian Plains tribes in the United States are three additional examples.
} 
unavailable land at higher elevations. Therefore a population that was probably smaller relative to later eras, quite possibly had a portfolio of better land from which to choose in producing crops. A result would have been more agricultural output (at the same or less work effort) compared with the centuries immediately following the Middle Ages.

It is well known that economic isolation, in the form of little trade beyond local interaction, also characterized life during the Middle Ages, at least relative to later centuries when regional commodity markets developed significantly. Anthropometric historians have noted the benefits to health and average heights of geographic isolation, low population density, or lack of commercial development for outlying areas within Sweden, Austria-Hungary, Japan, Ireland, and the United States (Sandberg and Steckel, 1987; Komlos, 1989; Shay, 1986; Margo and Steckel, 1982, 1992; Nicholas and Steckel, 1997; Cuff, 1998). The protective effect of isolation, in the era before effective public health, probably operated through insulation from communicable diseases. In this regard, it is notable that the bubonic plague made its dramatic appearance in the significant revival of trade during the late Middle Ages.

Urban areas were bad for health, as established from their high mortality rates and the small statures of those who resided in such places for a significant portion of their childhood growing years. To my knowledge, this demographic phenomenon was found in all areas of the world until the late nineteenth or early twentieth centuries, when public health measures and improvements in personal hygiene significantly reduced exposure to pathogens. Moderately large cities were absent from northern Europe until the late Middle Ages (for discussions of urban growth see De Vries, 1984; Hohenberg and Lees, 1985). As late as the end of the $13^{\text {th }}$ century, significant urbanization was confined 
mainly to southern Europe, in northern Italian towns such as Milan, Florence, Venice and Genoa, each of which probably exceeded 100,000 in population. At this time, Paris was the only city in northern Europe that may have fallen into this category. The southern Low Countries were moderately urbanized by the late Middle Ages (the $14^{\text {th }}$ century), but the largest city, Ghent, probably had no more than 50,000 inhabitants, while London and Cologne held fewer than 40,000 people at this time. Therefore, the overwhelmingly rural distribution of the population was an asset for health.

Possible factors in the health decline. A cooling trend began around 1200 and by the $14^{\text {th }}$ century, weather related events began to cause havoc in northern Europe (Fagan, 2000). By the late $14^{\text {th }}$ century the Vikings had abandoned Greenland and in the next century England no longer cultivated wine. By 1600, when the coldest two centuries of the Little Ice Age began, pack ice surrounded Iceland for much of the year, the Thames River often froze during the winter, glaciers advanced significantly in the Alps, and vast schools of cod had long since left European waters for warmer temperatures of the western Atlantic. The climate change was likely to have imposed greater economic and health costs on northern Europe where food production existed under weather conditions that were closer to the margin.

Important for agricultural production and health, the climate change was irregular. Imbedded within the general cooling period of 500-600 years were numerous seesaws of 15 to 40 years duration, several of which are visible in Figure 11. The changing weather patterns made it difficult for individuals alive at the time to identify true long-term trends, which were noticeable only with intergenerational perspective. The lack of knowledge about actual trends postponed adaptations to the cooling climate, and during temporary 
reversals of cooling, encouraged investments in ways of farming and living that later proved unsuccessful.

Urbanization and growth of trade that began in the late Middle Ages gathered steam in the $16^{\text {th }}$ and $17^{\text {th }}$ centuries. In northern Europe, there was only one city of 100,000 or more people in 1500 (De Vries, 1984, 73). By 1600 the number of people living in such places had quadrupled, and within another century it had tripled again. As height studies for the late eighteenth and early nineteenth centuries show, large cities were particularly hazardous for health, acting as reservoirs for the spread of communicable diseases (Steckel and Floud, 1997, chapter 11). Therefore, it would not be surprising if urbanization following the Middle Ages contributed to an overall decline in health.

The spread of disease that began with revival of trade and urbanization were reinforced by another source of pathogens that began in the late 1400s, and later intensified: global exploration and trade. The voyages of Columbus and Vasco da Gama were merely the first of thousands by which Europeans acquired global information that was used to build and maintain colonial empires. Within 300 years, Europeans had mapped most of the globe and established numerous colonies or trading centers on all continents or islands significant for producing saleable products. Syphilis is only one of numerous diseases that spread during this era. It is well known that the early stages of globalization began in the late 1400s and eventually led to the world-wide diffusion of many diseases into previously isolated regions or continents (Crosby, 1972, 1986).

As a measure of net nutrition, average height is adept at measuring a population's consumption of basic necessities such as food, clothing, shelter, and medical care. In 
countries with high levels of per capita GDP, most people have enough of these to satisfy basic needs. But in poor countries or among the poor in moderate-income countries, large numbers of people are biologically stressed or deprived, which leads to stunting. In addition to income, average height is therefore sensitive to the degree of inequality (Steckel, 1983; 1995). It is difficult to acquire information about income or wealth inequality in the distant past, but Hoffman et al. (2000) have been ingenuous in assembling related information by using information on the prices of products heavily consumed by the rich or by the poor. In their study of price patterns for staple foods and fuels relative to the prices of luxury goods, such as servants, they find that real inequality rose considerably during the $16^{\text {th }}$ century and remained high until the 20th century. It was during the era from 1500 to 1650 , however, that the rich benefited most from soaring land rents (a source of income for many of the well-off) while the poor faced higher prices for food, housing and land. As far as Hoffman et al. can tell, this trend persisted throughout most of Europe. Since the poor comprised a large segment of the population, it is plausible to believe that growing inequality could have increased biological stress in ways that reduced average heights in the centuries immediately following the Middle Ages.

Although state building could be credited, in many cases, with eventually improving economic efficiency, the early stages of the process also absorbed resources, cost human lives in conflict, and may have increased inequality. Someone might be able to argue that religious wars and conflicts improved health when or shortly after they occurred, but I find it difficult to imagine a mechanism. From the War of the Roses in the late $15^{\text {th }}$ century and the Reformation in the early $16^{\text {th }}$ century, many parts of Europe 
were in sporadic and sometimes protracted conflict or turmoil until the conclusion of the Napoleonic wars in 1815.

It would be premature to attempt to identify an era that was the worst in the last millennium for European health and nutrition, but the $17^{\text {th }}$ century is a leading candidate. Contributors to The General Crisis of the Seventeenth Century (Geoffrey Parker and Lesley Smith, eds., 1997) focus on Europe but argue that the hardship probably spread well-beyond this region. During this century numerous adverse forces acted together. It was part of the coldest period of the Little Ice Age, and subsistence crises were numerous. Religious turmoil was raging as signified by the Thirty Years War, and political instability was marked by the English Civil War and by numerous peasant uprisings. Economic inequality was intense as indicated by the rise in the price of necessities relative to luxuries. Global colonization and the associated spread of diseases were in full swing, as was a rapid increase in the number of large cities. It remains, however, to connect these events to changes in average stature.

Height Recovery. The forces that led to increasing average heights are difficult to pinpoint without additional evidence on the times and places where increases occurred. It is hard to see how industrialization could have reduced exposure to pathogens. Growing population congestion, migration and trade associated with the process were likely to have spread communicable diseases. If correct, one must look to other factors, such as the retreat of the Little Ice Age that could have contributed to higher yields in agriculture. There were also other sources of improving productivity in agriculture that began in the $18^{\text {th }}$ century, such as new crops for forage and food, new crop rotations, enclosures, better drainage systems, and mechanical equipment. McKeown (1983) has been the strongest 
advocate for better diets in improving health, and Fogel (1994) has used data on average heights and agricultural production to buttress and quantify this point of view. Razzell (1993) and Livi-Bacci (1983) have raised doubts or downplayed the contribution of nutritional inputs to improving health, citing factors such as the independence of many diseases from nutrition, human adaptability to food availability, smallpox inoculation, and changing virulence of diseases.

While more research should be done, connections have been made between rising heights and improving diets in specific countries. Weir (1997) argues that growing meat consumption contributed significantly to rising heights in nineteenth-century France. Sandberg and Steckel (1980) suggest that diffusion of potatoes was important to improvements in stature in Sweden in the early nineteenth century. More generally, dietary improvement in nineteenth-century Europe was made possible by technical improvements, such as light iron plows, steam threshers, mechanical harvesters, and commercial fertilizers, as well as by agrarian reforms such as enclosures or emancipation of serfs (Jones, 1968; Trow-Smith, 1967; Tracy, 1964). In the middle of the nineteenth century, diets also received a boost from the free trade movement. This and greater speed and lower transportation costs on long ocean voyages made it feasible to import foodstuffs from Australia and from the land-rich countries in the Western Hemisphere, principally the US, Canada, and Argentina (O'Rourke and Williamson, 1999). There is also evidence that public health measures, though based on an inaccurate theory of disease causation, were somewhat effective in reducing mortality rates in cities (Szreter, 1988). 
An increase in average height may have been assisted by gains in consumption per person that followed from reductions in conflicts that absorbed resources. Although there were some revolutions and assorted small wars in Europe during the nineteenth century, the Napoleonic Wars, which ended in 1815, was the last major conflict until World War I. Some religious strife persisted, but in fewer places and at lower levels than existed during the Reformation.

\section{Concluding Remarks}

While there are qualifications to be noted, the major empirical finding reported in this paper is the U-shaped pattern in average heights from the early Middle Ages through the late nineteenth century in northern Europe. After a long period of approximate stability at levels that were impressive even by standards of the late nineteenth century, heights declined sometime after the end of the Middle Ages. Plausibly, the height decline might be linked with climate change that accompanied the onset of the little ice age; growing inequality; urbanization; the global spread of diseases after the late 1400s; and conflicts associated with state building and religion. Because it is reasonable to believe that greater exposure to pathogens accompanied industrialization, and there is evidence of growing efficiency in agriculture and greater trade in foodstuffs, it is reasonable to link height gains during the early and mid nineteenth century with dietary improvements.

Much research remains to be done on the exact time-path of average heights, and substantially more information from skeletal evidence is available. A large research program is now in the planning stages to gather this evidence and analyze it in light of 
related information on climate and of socioeconomic information from historical sources and from the archaeological record.

For over half a century economic historians have focused on the question of whether there was immizeration during industrialization, a debate that has split researchers into camps of optimists and pessimists. This is and continues to be an interesting topic for research. But with the perspective of 1000 years of history, whatever happened with regard to downturns in welfare during this era, they were likely small compared to the vast changes that probably occurred since the early Middle Ages. Therefore, economic historians who are inspired by variation and diversity in the historical record would do well to consider this much broader time span of evidence. 


\section{References}

Allen, Robert C., "The Great Divergence: Wages and Prices in Europe, 1375-1913." Paper presented at the Economic History Association meetings, Durham, North Carolina, September, 1998.

Arcini, Caroline, "Health and Disease in Early Lund: Osteo-Pathologic Studies of 3,305 Individuals Buried in the First Cemetery Area of Lund, 990-1536.” Archaeologica Lundensia 8 (1999).

Bennike, Pia, Palaeopathology of Danish Skeletons. Denmark: Akademisk Forlag, 1985.

Boldsen, Jesper. "A statistical evaluation of the basis for predicting stature from lengths of long bones in European populations." American Journal of Physical Anthropology 65 (1984), 305-311.

Crosby, Alfred W., Jr., The Columbian Exchange: Biological and Cultural Consequences of 1492. Westport, Conn.: Greenwood Press, 1972.

Crosby, Alfred W., Ecological Imperialism: The Biological Expansion of Europe, 9001900. Cambridge: Cambridge University Press, 1986.

Cuff, Timothy, The Effects of Economic Development on the Biological Standard of Living: Market Integration and Human Stature in Antebellum Pennsylvania. Ph.D. dissertation, University of Pittsburgh, 1998.

De Vries, Jan, The Economy of Europe in an Age of Crisis, 1600-1750. New York: Cambridge University Press, 1976.

De Vries, Jan, European Urbanization, 1500-1800. Cambridge: Harvard University Press, 1984. 
Drukker, J.W. and Tassenaar, Vincent, "Paradoxes of Modernization and Material WellBeing in the Netherlands during the Nineteenth Century.” In Richard H. Steckel and Roderick Floud (eds.), Health and Welfare during Industrialization. Chicago: University of Chicago Press, 1997. Pp. 331-77.

Engerman, Stanley L., "The Standard of Living Debate in International Perspective: Measures and Indicators.” In Richard H. Steckel and Roderick Floud (eds.), Health and Welfare during Industrialization. Chicago: University of Chicago Press, 1997. Pp. 17-45.

Fagan, Brian, The Little Ice Age: How Climate Made History, 1300-1850. New York: Basic Books, 2000.

Floud, Roderick and Harris, Bernard, "Health, Height, and Welfare: Britain, 1700-1980." In Richard H. Steckel and Roderick Floud (eds.), Health and Welfare during Industrialization. Chicago: University of Chicago Press, 1997. Pp. 91-126. Fogel, Robert William, "Nutrition and the Decline in Mortality since 1700: Some Preliminary Findings.” In Stanley L. Engerman and Robert E. Gallman (eds.), Long-Term Factors in American Economic Growth. Chicago: University of Chicago Press, 1985. Pp. 439-555.

Gejvall, Nils Gustaf. Westerhus; Medieval Population and Church in the Light of Skeletal Remains. Lund: H. Ohlssons boktr., 1960.

Gilberg, Rolf, “Stengade-vikingernes skeletter.” In Jorgen Skaarup (ed.), Stengade II: en langelandsk Gravplads med grave fra romerskjernalder og vikingetid. Rudkobing: Langelands Museum, 1976. Pp. 220-27. 
Hanson, C. "Population-Specific Stature Reconstruction for Medieval Trondheim, Norway.” International Journal of Osteoarchaeology 2 (1992), 289-95.

Hoffman, Philip T., Jacks, David, Levin, Patricia A. and Lindert, Peter H., "Prices and Real Inequality in Europe since 1500.” Agricultural History Center working paper No. 102, October 2000. Davis, Calif.

Hohenberg, Paul M. and Lees, Lynn Hollen, The Making of Urban Europe, 1000-1950. Cambridge: Harvard University Press, 1985.

Holck, Per, Cremated Bones. A medical-anthropological study of an archaeological material on cremation burials. Antropologiske skrifter nr. 1c Anatomical Institute, University of Oslo, 1997.

Holck, Per and Kvaal, Sigrid, Skjelettene Fra Clemengkirken I Oslo. Antropologiske skrifter nr. 5, Anatomisk institutt, Universitetet I Oslo, 2000.

Honda, Gail, "Differential Structure, Differential Health: Industrialization in Japan, 1868-1940.” In Richard H. Steckel and Roderick Floud (eds.), Health and Welfare during Industrialization. Chicago: University of Chicago Press, 1997. Pp. 251-84. Huber, Neil M., "The Problem of Stature Increase: Looking from the Past to the Present. In D.R. Brothwell (ed.), The Skeletal Biology of Earlier Human Populations. Pegamon Press, Oxford, 1968. Pp. 67-102.

Janssen, H.A.M. and Maat, G.J.R. "Canons Buried in the "Stiftskapel” of the Saint Servaas Basilica at Maastricht, A.D. 1070-1521: A Paleopathological Study,” Barge's Anthropologica 5, $2^{\text {nd }}$ ed. (1999), Leiden.

Jones, E. L., The Development of English Agriculture, 1815-1873. London: Macmillan, 1968. 
Komlos, John, Nutrition and Economic Development in the Eighteenth-Century Habsburg Monarchy. Princeton: Princeton University Press, 1989.

Komlos, John, "Shrinking in a Growing Economy? The Mystery of Physical Stature during the Industrial Revolution,” Journal of Economic History 58 (1998), 779-802

Komlos, John, Hau, Michel and Bourguinat, Nicholas, "The Anthropometric History of Early-Modern France.” Unpublished manuscript. University of Munich, 2001.

Kunitz, Stephen J., "Making A Long Story Short: A Note on Men's Height and Mortality in England from the First Through the Nineteenth Centuries," Medical History 31 (1987), 269-80.

Livi-Bacci, Massimo, "The Nutrition-Mortality Link in Past Times: A Comment," Journal of Interdisciplinary History 14 (1983): 293-98.

Maat, G.J.R., "A Search for Secular Growth Changes in the Netherlands Preceding 1850.” In J. Borms, R. Hauspie, A. Sand, C. Susanne and M. Hebbelinck (eds.), Human Growth and Development. Plenum Press: New York, 1984. Pp. 185-91. Maat, G.J.R., Mastwijk, R.W. and Sarfatij, H., Een Fysisch Anthropologisch Onderzoek van Begravenen bij het Minderbroedersklooster te Dordrecht, circa 1275-1572 AD. Amersfoort: Riijksdienst voor her Oudheidkundig Bodemonderzoek, 1998.

Malcolm, L.A., "Ecological Factors Relating to Child Growth and Nutritional Status." In Alexander F. Roche and Frank Falkner (eds.), Nutrition and Malnutrition: Identification and Measurement. New York: Plenum Press, 1974. Pp. 329-52. Margo, Robert A., and Steckel, Richard H., "The Nutrition and Health of Slaves and Antebellum Southern Whites.” In Robert William Fogel and Stanley L. Engerman 
(eds.), Without Consent or Contract: Conditions of Slave Life and the Transition to

Freedom. New York: W.W. Norton, 1992. Pp. 508-21.

Margo, Robert A., and Steckel, Richard H., "The Heights of American Slaves: New

Evidence on Slave Nutrition and Health,” Social Science History 6 (1982), 516-38.

Martorell, Reynaldo and Jean-Pierre Habicht, "Growth in Early Childhood in Developing

Countries." In Frank Falkner and J.M. Tanner (eds.), Human Growth: A

Comprehensive Treatise, Vol. 3. New York: Plenum Press, 1986. Pp. 241-62.

McKeown, Thomas, "Food, Infection, and Population,” Journal of Interdisciplinary

History 14 (1983): 227-47.

Molleson, Theya and Margaret Cox The Spitalfields Project: Volume 2--The

Anthropology. Council for British Archaeology Research Report 86. York, 1993.

Munter, A. Heinrich "A study of the lengths of the long bones of the arms and legs in man, with special reference to Anglo-Saxon Skeletons" Biometrika XXVIII (1928), 258-294.

Nicholas, Stephen and Steckel, Richard H., "Tall But Poor: Living Standards of Men and Women in Pre-Famine Ireland," with Stephen Nicholas, Journal of European Economic History 26 (1997), 105-34.

O’Rourke, Kevin H. and Williamson, Jeffrey G., Globalization and History: The Evolution of a Nineteenth-Century Atlantic Economy. Cambridge, Mass: MIT Press, 1999.

Parker, Geoffrey and Smith, Lesley M. (eds.), The General Crisis of the Seventeenth Century. New York: Routledge, 1997. 
Pope, Clayne L., “Adult Mortality in America before 1900: A View from Family Histories.” In Claudia Goldin and Hugh Rockoff (eds.), Strategic Factories in Nineteenth Century American Economic History. Chicago: University of Chicago Press, 1992. Pp. 267-96.

Razzell, Peter, "The Growth of Population in Eighteenth-Century England: A Critical Reappraisal," Journal of Economic History 53 (1993): 743-71.

Sandberg, Lars G. and Steckel, Richard H., "Was Industrialization Hazardous to Your Health? Not in Sweden!” In Richard H. Steckel and Roderick Floud (eds.), Health and Welfare during Industrialization. Chicago: University of Chicago Press, 1997. Pp. 127-59.

Sandberg, Lars G., and Steckel, Richard H., "Heights and Economic History: The Swedish Case.” Annals of Human Biology 14 (1987): 101-110.

Sandberg, Lars and Richard H. Steckel, "Soldier, Soldier, What Made You Grow So Tall? A Study of Height, Health, and Nutrition in Sweden, 1720-188," Economy and History 23 (1980): 91-105.

Schmidt, I.M., M.H. Jorgensen, and K.F. Michaelsen, "Height of Conscripts in Europe: Is Postneonatal Mortality a Predictor?," Annals of Human Biology 22 (1995), 57-67. Shay, Ted, "The Stature of Military Conscripts: New Evidence on the Standard of Living in Japan.” Paper given at the 1986 Social Science History Association meetings, St. Louis, Missouri.

Steckel, Richard H., "Height and Per Capita Income," Historical Methods 16 (1983): 1-7. Steckel, Richard H., "Stature and the Standard of Living," Journal of Economic Literature 33 (1995), 1903-40.. 
Steckel, Richard H., "Strategic Ideas in the Rise of the New Anthropometric History and Their Implications for Interdisciplinary Research,” Journal of Economic History 58 (1998), 803-21.

Steckel, Richard H., "Industrialization and Health in Historical Perspective.” In David Leon and Gill Walt (eds.), Poverty, Inequality and Health. Oxford: Oxford University Press, 2000. Pp. 37-57.

Steckel, Richard H., "Health, Nutrition and Physical Wellbeing." In Historical Statistics of the United States: Millennial Edition. Edited by Susan Carter, Scott Gartner, Michael Haines, Alan Olmstead, Richard Sutch, and Gavin Wright. New York: Cambridge University Press, forthcoming 2002.

Steckel, Richard H. and Roderick Floud (eds.), Health and Welfare during Industrialization. Chicago: University of Chicago Press, 1997.

Steffensen, Jon, Stature as a Criterion of the Nutritional Level of Viking Age Icelanders. Arbok hins islenzka fornleifafelags, fylgirit. 1958.

Szreter, Simon, “The Importance of Social Intervention in Britain's Mortality Decline c. 1850-1914: A Reinterpretation of the Role of Public Health.” Social History of Medicine 1 (1988), 1-37.

Tracy, Michael, Agriculture in Western Europe. New York: Prager, 1964.

Trotter, M. and Gleser, G.C., "Estimation of Stature from Long Bones of American Whites and Negroes. American Journal of Physical Anthropology 10 (1952), 463514.

Trow-Smith, Robert, Life from the Land: The Growth of Farming in Western Europe. London: Longmans. 1967. 
Twarog, Sophia, "Heights and Living Standards in Germany, 1850-1939: The Case of Württemberg.” In Richard H. Steckel and Roderick Floud (eds.), Health and Welfare during Industrialization. Chicago: University of Chicago Press, 1997. Pp. 285-330.

Weir, David R. "Economic Welfare and Physical Well-Being in France, 1750-1990." In Richard H. Steckel and Roderick Floud (eds.), Health and Welfare during Industrialization. Chicago: University of Chicago Press, 1997. Pp. 161-200.

Werdelin, Lars, “The Stature of Some Medieval Swedish Populations,” Fornvännen 80 (1985), 133-41.

Whitwell, Greg, de Souza, Christine, and Nicholas, Stephen, "Height, Health, and Economic Growth in Australia, 1860-1940.” In Richard H. Steckel and Roderick Floud (eds.), Health and Welfare during Industrialization. Chicago: University of Chicago Press, 1997. Pp. 379-422. 
Table 1: Average Height of Adult Men, Life Expectancy and Percentage Urban by Stage of Industrialization

\begin{tabular}{|c|c|c|c|c|}
\hline Country & Dates & Stature & Life Expectancy & $\%$ Urban \\
\hline \multicolumn{5}{|c|}{ Preindustrial Phase } \\
\hline UK & $1720-1760$ & 165.1 & 33.7 & 22.6 \\
\hline US & $1800-1820$ & 173 & 45.3 & 6.9 \\
\hline France & $1800-1820$ & 164.1 & 36 & 19 \\
\hline the Netherlands & $1830-1850$ & 164 & 35 & 38 \\
\hline Sweden & $1830-1850$ & 168 & 42.1 & 9.7 \\
\hline Germany & $1830-1850$ & & 36.9 & 30.5 \\
\hline Australia & $1840-1860$ & 172.5 & 46 & 30 \\
\hline Japan & $1868-1880$ & 155.3 & 36 & 34.5 \\
\hline \multicolumn{5}{|c|}{ Early Industrial Phase } \\
\hline UK & $1760-1800$ & 168.2 & 36 & 29.4 \\
\hline US & $1820-1850$ & 172.4 & 41.7 & 10.5 \\
\hline France & $1820-1850$ & 164.4 & 39.3 & 22 \\
\hline the Netherlands & $1850-1870$ & 165.9 & 40 & 44 \\
\hline Sweden & $1850-1870$ & 169.1 & 43.9 & 11.2 \\
\hline Germany & $1850-1870$ & 166.2 & 37.6 & 34.4 \\
\hline Australia & $1860-1890$ & 172 & 48 & 42 \\
\hline Japan & $1880-1900$ & 157 & 38 & 50 \\
\hline \multicolumn{5}{|c|}{ Middle Industrial Phase } \\
\hline UK & $1800-1830$ & 170.7 & 38.6 & 38.7 \\
\hline US & $1850-1880$ & 170.6 & 40.9 & 22.3 \\
\hline France & $1850-1880$ & 165.4 & 41 & 31 \\
\hline the Netherlands & 1879-1900 & 168.6 & 45 & 46 \\
\hline Sweden & $1870-1900$ & 171.4 & 49.3 & 17.2 \\
\hline Germany & $1870-1890$ & 167.5 & 38.9 & 43.6 \\
\hline Australia & $1890-1920$ & 172 & 59.2 & 53 \\
\hline Japan & $1900-1920$ & 158.8 & 44 & 60 \\
\hline \multicolumn{5}{|c|}{ Late Industrial Phase } \\
\hline UK & $1830-1870$ & 166.9 & 39.5 & 54.1 \\
\hline US & $1880-1910$ & 170.2 & 45.6 & 37.2 \\
\hline France & $1880-1910$ & 166.7 & 45.5 & 39 \\
\hline Germany & 1890-1913 & 169.7 & 46.8 & 56.1 \\
\hline the Netherlands & $1900-1925$ & 172 & 55.2 & 56 \\
\hline Sweden & $1900-1925$ & 173.5 & 57.4 & 25.7 \\
\hline Australia & $1920-1940$ & 173.2 & 65.4 & 60 \\
\hline Japan & $1920-1940$ & 160 & 47 & 75.5 \\
\hline
\end{tabular}

Source: Steckel and Floud (1997), Table 11.2, p. 425. 
Table 2: Average Heights in Northern Europe Estimated from Adult Male Skeletons

\begin{tabular}{|l|l|c|c|l|}
\hline Era & Place & Avg. Height $(\mathrm{cm})$ & Sample Size & Source \\
\hline $9-11^{\text {th }} \mathrm{C}$ & Iceland & 172.3 & 22 & Steffensen (1958) \\
\hline $9-17^{\text {th }} \mathrm{C}$ & Iceland & 172.2 & 71 & Steffensen (1958) \\
\hline $10-11^{\text {th }} \mathrm{C}$ & Sweden & 176.0 & 8 & Gilberg (1976) \\
\hline $11-12^{\text {th }} \mathrm{C}$ & Iceland & 172.0 & 27 & Steffensen (1958) \\
\hline $11-17^{\text {th }} \mathrm{C}$ & Iceland & 171.0 & 16 & Steffensen (1958) \\
\hline $12^{\text {th }} \mathrm{C}$ & Norway & 170.2 & 42 & Hanson (1992) \\
\hline $12^{\text {th }} \mathrm{C}$ & Britain & 168.4 & 233 & Munter (1928) \\
\hline $12-13^{\text {th }} \mathrm{C}$ & Norway & 172.2 & $*$ & Huber (1968) \\
\hline $12-16^{\text {th }} \mathrm{C}$ & Iceland & 175.2 & 6 & Steffensen (1958) \\
\hline $13^{\text {th }} \mathrm{C}$ & Denmark & 172.2 & 31 & Boldsen (1984) \\
\hline $13^{\text {th }} \mathrm{C}$ & Sweden & 174.3 & 66 & Gejvall (1960) \\
\hline $13-14^{\text {th }} \mathrm{C}$ & England & 171.8 & $*$ & Huber (1968) \\
\hline Middle Ages & Sweden & 170.4 & 457 & Steffensen (1958) \\
\hline Middle Ages & Denmark & 172.0 & 190 & Bennike (1985) \\
\hline Middle Ages & Denmark & 172.6 & 43 & Bennike (1985) \\
\hline Middle Ages & Norway & 172.1 & 314 & Holck \&Kvall (2000) \\
\hline Middle Ages & Denmark & 175.2 & 27 & Holck (1997) \\
\hline Middle Ages & Norway & 167.2 & 1792 & Holck (1997) \\
\hline Middle Ages & Sweden & 170.4 & 457 & Werdelin (1985) \\
\hline $13-16^{\text {th }} \mathrm{C}$ & Holland & 172.5 & 87 & Maat et al. (1998) \\
\hline $11-16^{\text {th }} \mathrm{C}$ & Holland & 176.2 & 23 & Janssen and Maat (1999) \\
\hline $11-16^{\text {th }} \mathrm{C}$ & Sweden & $172.8^{\text {a }}$ & 499 & Arcini (1999) \\
\hline $17-18^{\text {th }} \mathrm{C}$ & Iceland & 169.7 & 17 & Steffensen (1958) \\
\hline $17-18^{\text {th }} \mathrm{C}$ & Holland & 166.0 & 41 & Maat (1984) \\
\hline
\end{tabular}


Table 2 (con’t)

\begin{tabular}{|l|l|c|c|l|}
\hline $17-18^{\text {th }} \mathrm{C}$ & Holland & $166.7^{\text {b }}$ & 102 & Maat (1984) \\
\hline $18^{\text {th }} \mathrm{C}$ & Iceland & 167.0 & 4 & Steffensen (1958) \\
\hline $18^{\text {th }} \mathrm{C}$ & Norway & 165.3 & 1956 & Holck (1997) \\
\hline $17-19^{\text {th }} \mathrm{C}$ & Iceland & 169.2 & 21 & Steffensen (1958) \\
\hline $18-19^{\text {th }} \mathrm{C}$ & Britain & 170.3 & 211 & Molleson \& Cox (1993) \\
\hline
\end{tabular}

a. Simple average across 7 combinations of sites and dates.

b. Based on a sample of 102 men and women who were indistinguishable based on skeletal remains, of which about one half were men as determined from written records. The overall average was adjusted upward for typical sexual dimorphism $(5 \mathrm{~cm})$, to estimate male heights. 


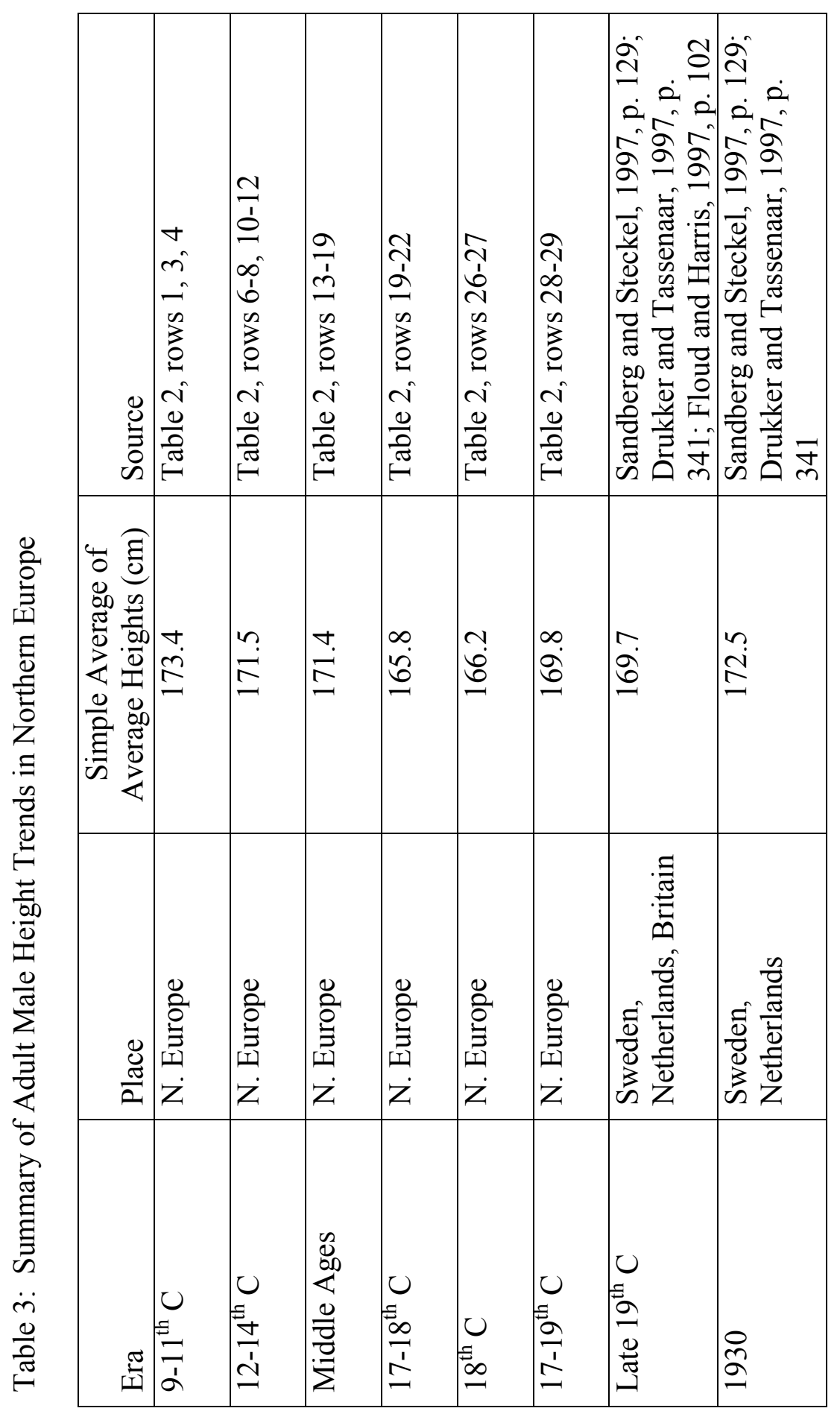




\section{List of Figures}

Figure 1: Life Expectancy and Adult Male Height, Late Industrial Period Source: Steckel (2000).

Figure 2: Adult Male Height and Per cent Urban

Source: Steckel (2000).

Figure 3: Average Height of Native Born Men in the United States by Birth Cohort Source: Steckel (2002, Figure 12)

Figure 4: Mean Heights of British Military Recruits

Source: Floud and Harris (1997)

Figure 5: Height of Conscripts in Sweden, 1820-1965

Source: Sandberg and Steckel (1997)

Figure 6: Median Height of Dutch Conscripts by Year of Conscription, 1818-1940 Source: Drukker and Tassenaar (1997)

Figure 7: Average Height of Conscripts in France at Age 20

Source: Weir (1997)

Figure 8: Per Capita GDP and Average Height of 20-Year Old Military Recruits in Japan, 1886-1940

Source: Honda (1997)

Figure 9: Heights of Württemberg Soldiers, 1852-57 to 1888-93 by Urban-Rural Status Source: Twarog (1997)

Figure 10: Heights of Australian Recruits, Five-Year Moving Averages

Source: Whitwell et al. (1997)

Figure 11: Historical Events, Temperature, and Climatic and Natural Events, 1000-2000. Source: Fagan (2000). 
Figure 1: Life Expectancy and Adult Height, Late Industrial Period

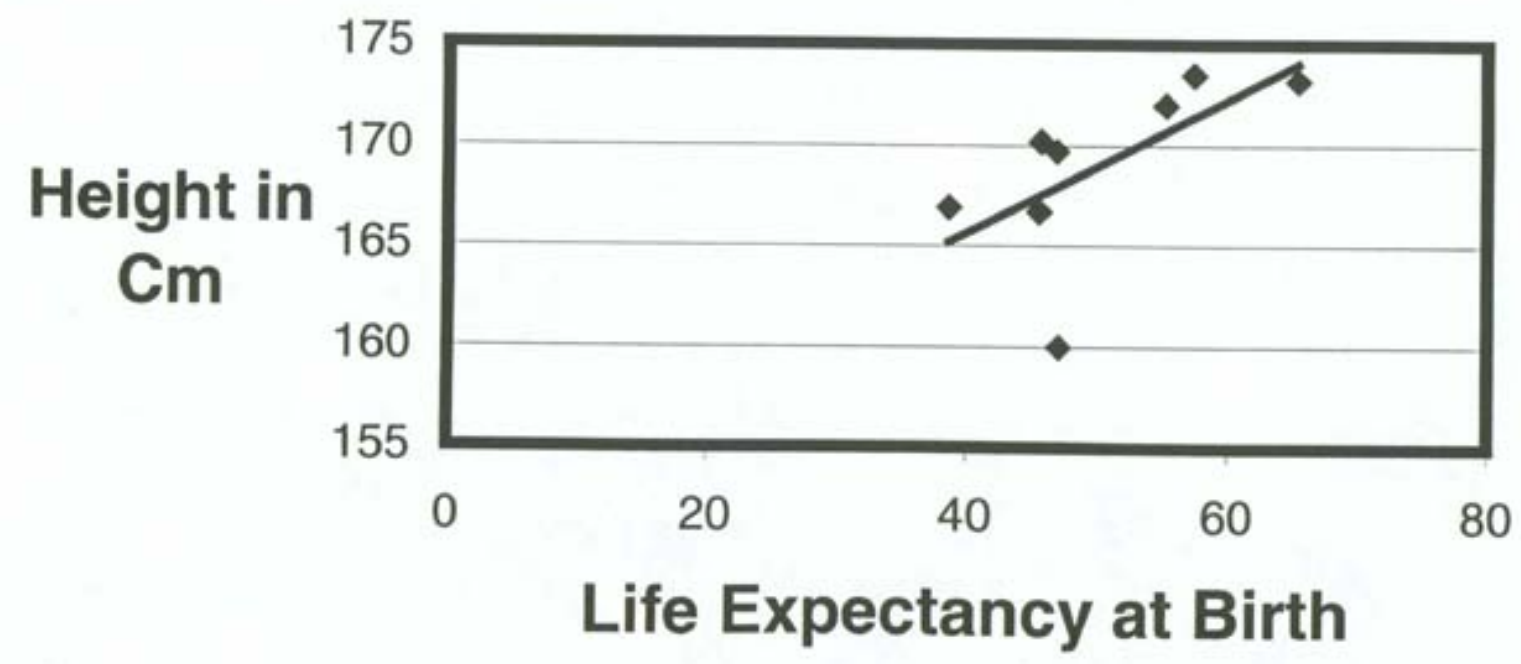

Source: Estimated from data in Steckel and Floud (1997, Table 11.2). 
Figure 2: Per Cent Urban and Average Male Height

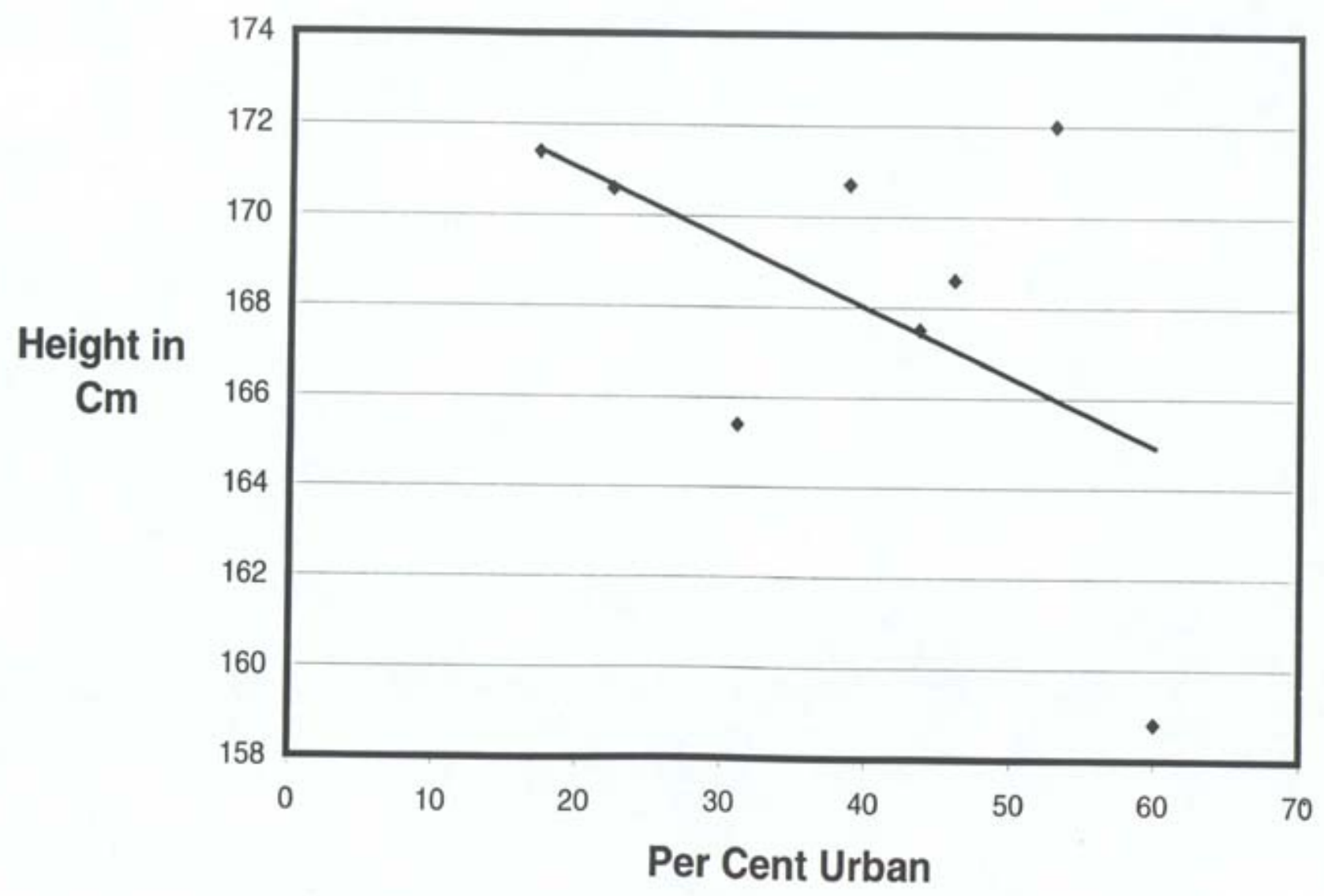

Source: Estimated from data in Steckel and floud (1997, Table 11.2). 
Figure 3: Heights of Native-born American Men and Women, by Year of Birth

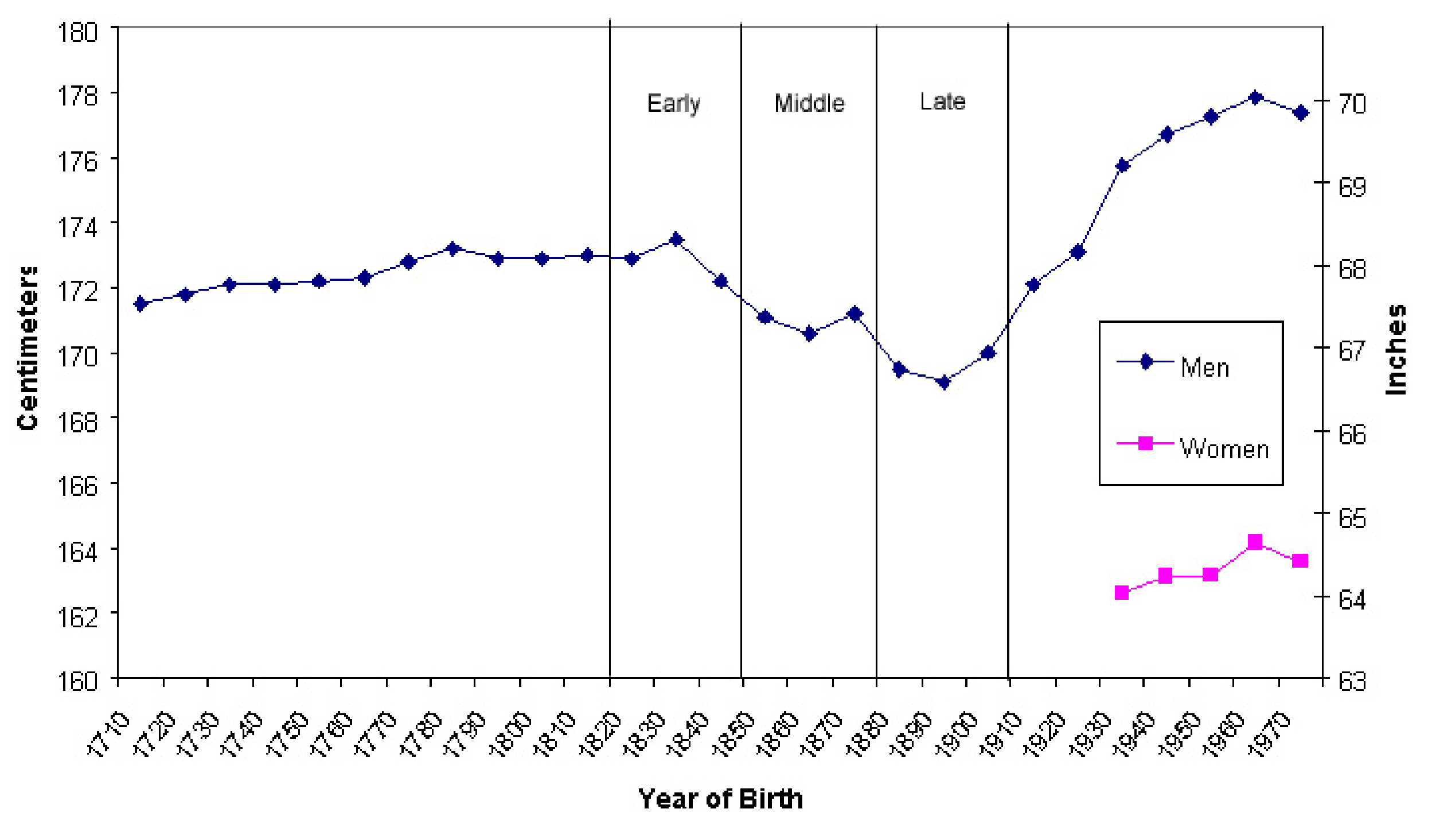


Figure 4: Mean Heights of British Military Recruits

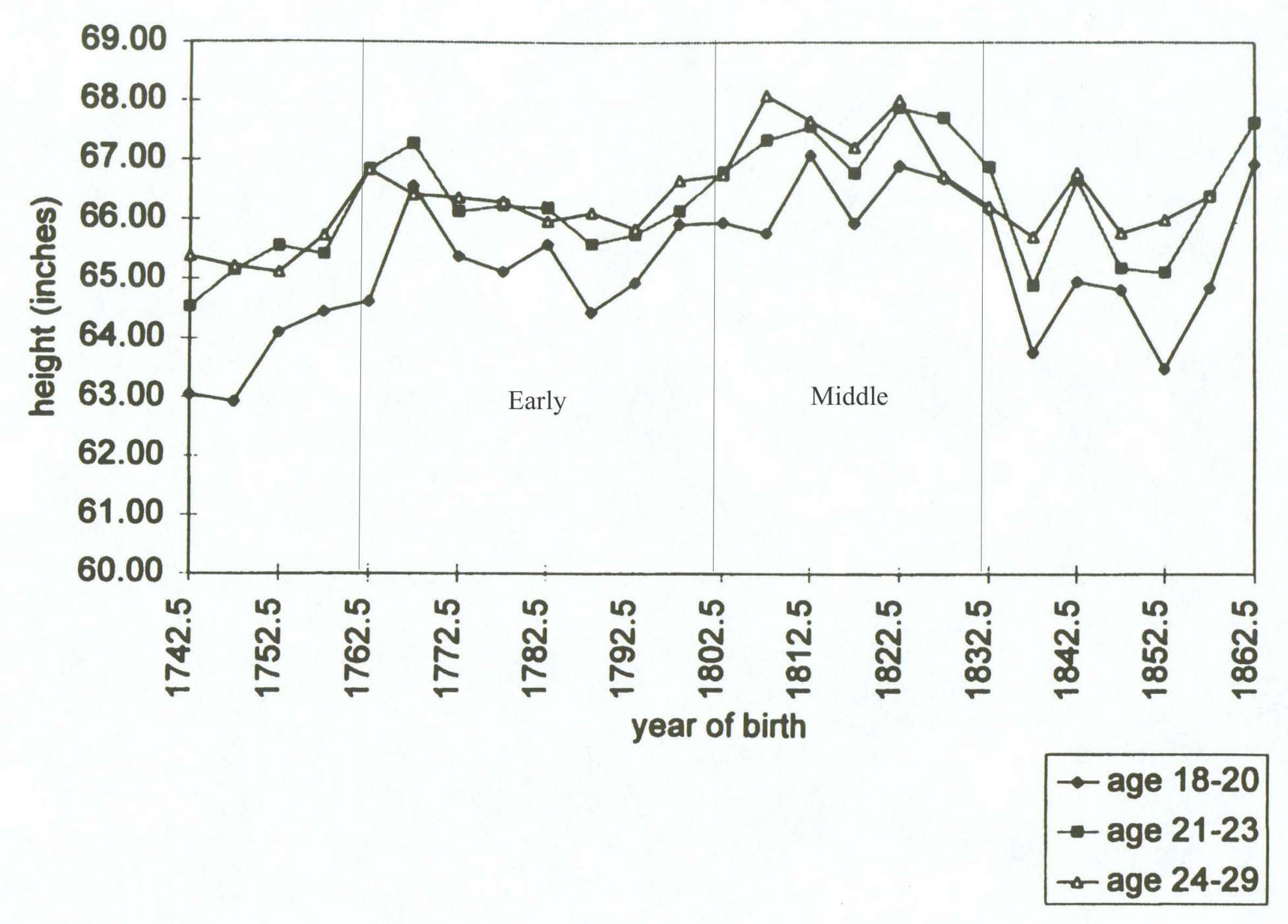

Source: Floud and Harris (1997). 
Figure 5: Heights of Conscripts in Sweden, 1820-1965

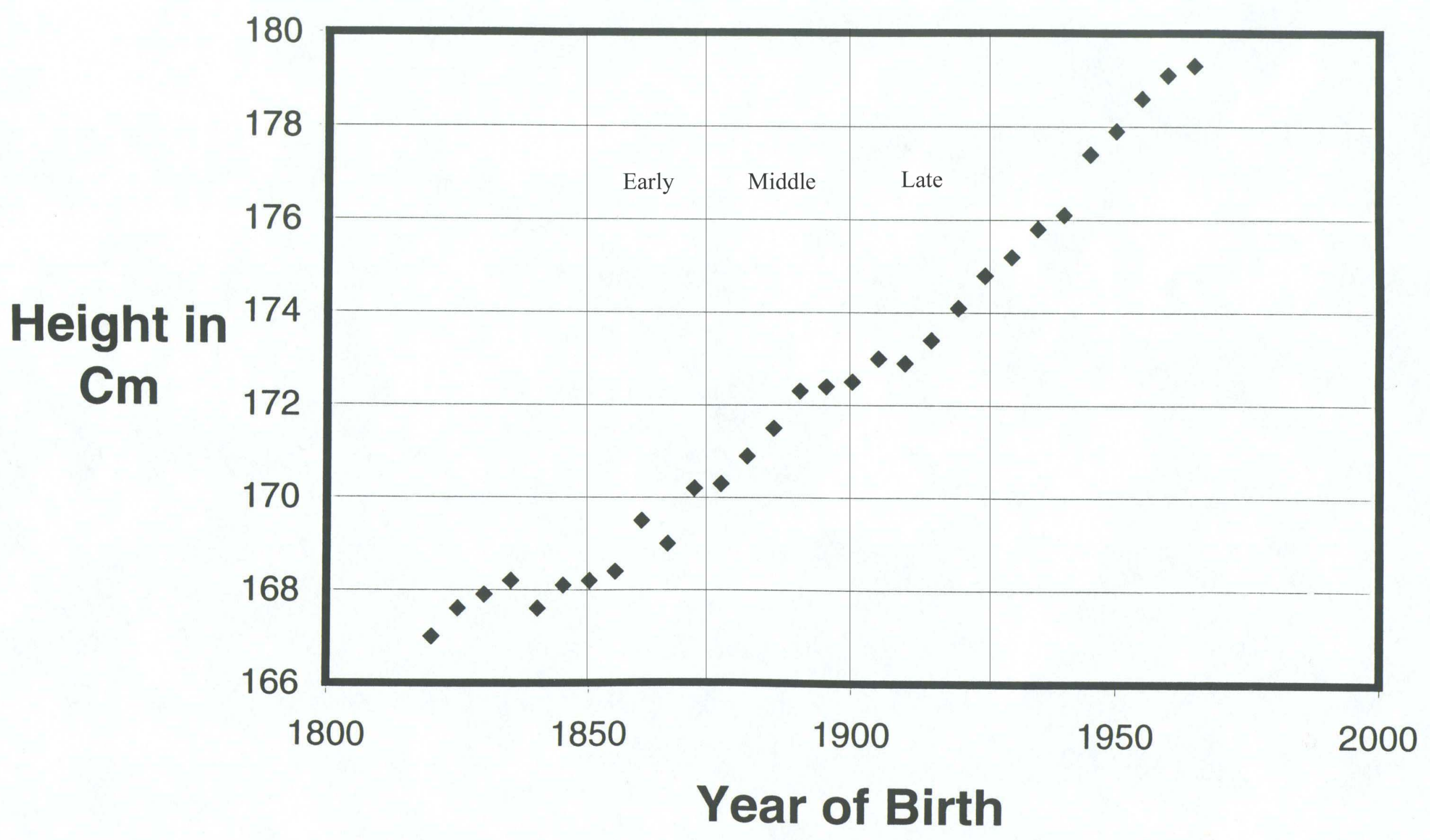

Source: Sandberg and Steckel (1997). 
Figure 6: Median Heights of Dutch Conscripts, 1818-1940

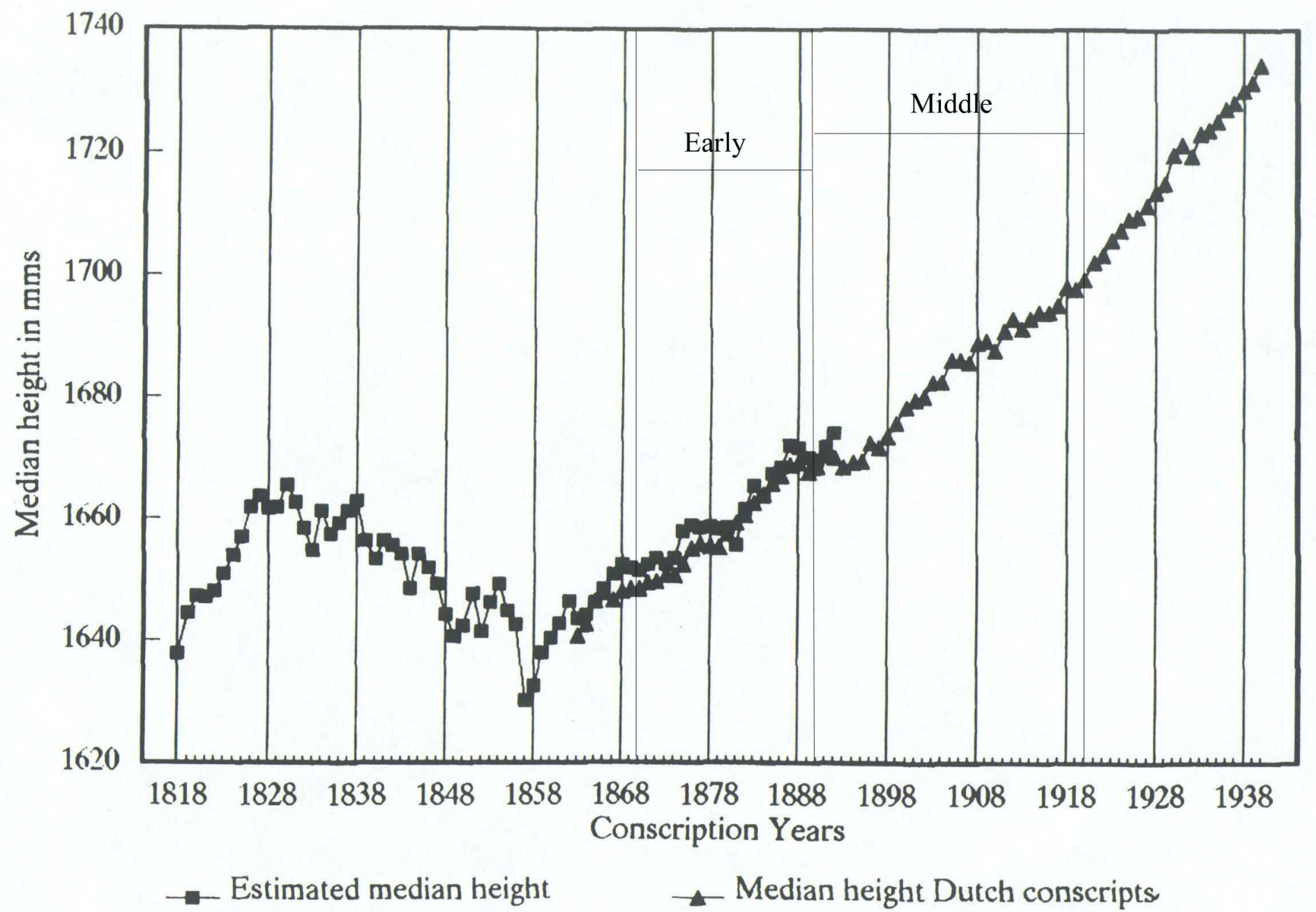

Source: Drukker and Tassenaar (1997). 
Figure 7 : Male Height at Age 20 In France, 1770-1980

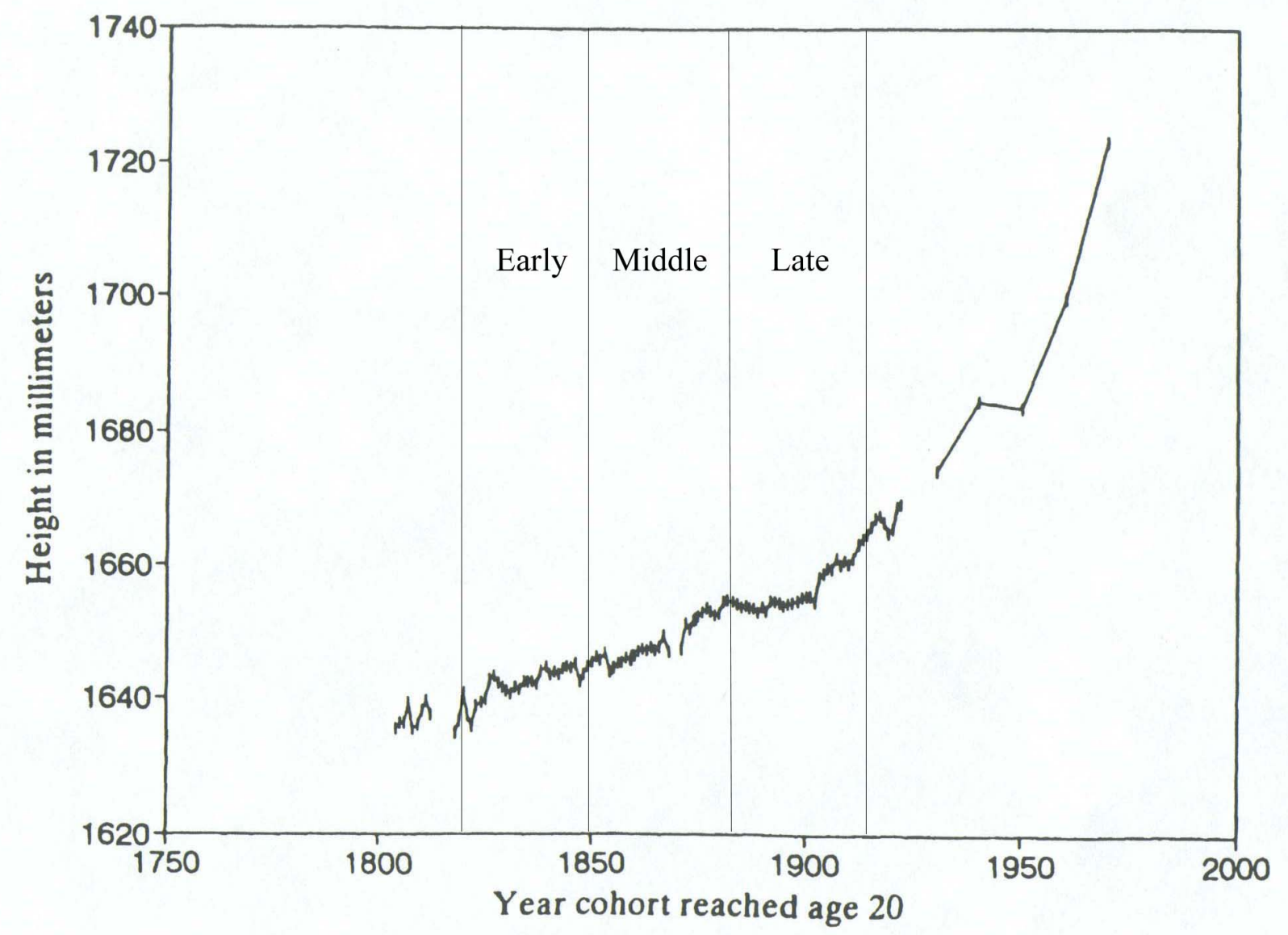

Source: Weir (1997) 
Figure 8: Per Capita GDP and Avearge Height of 20-year Old Recruits in Japan, 18861940.

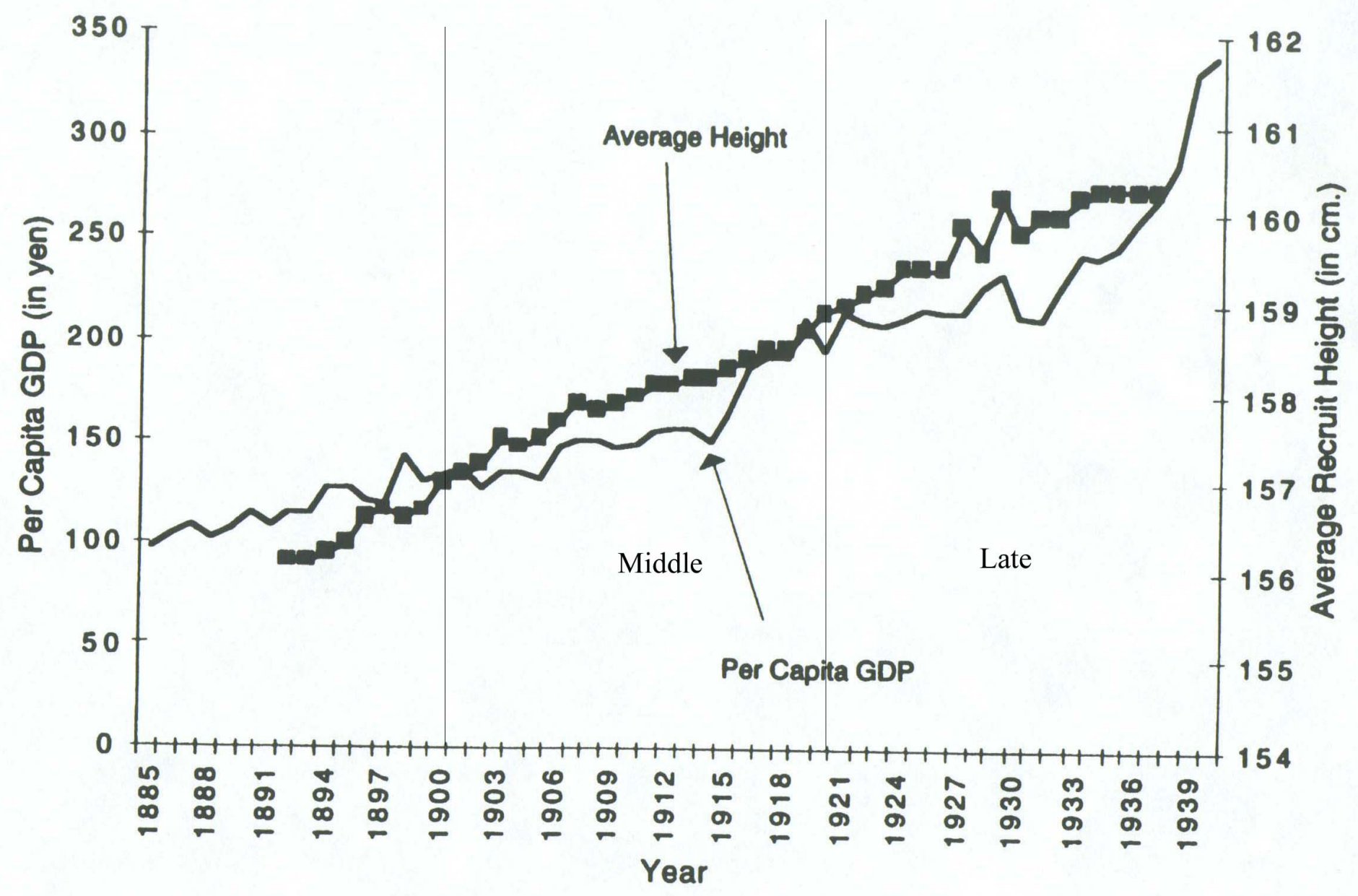

Source: Honda (1997). 
Figure 9: Heights of Württemberg Soldiers, 1852-57 to 1888-93

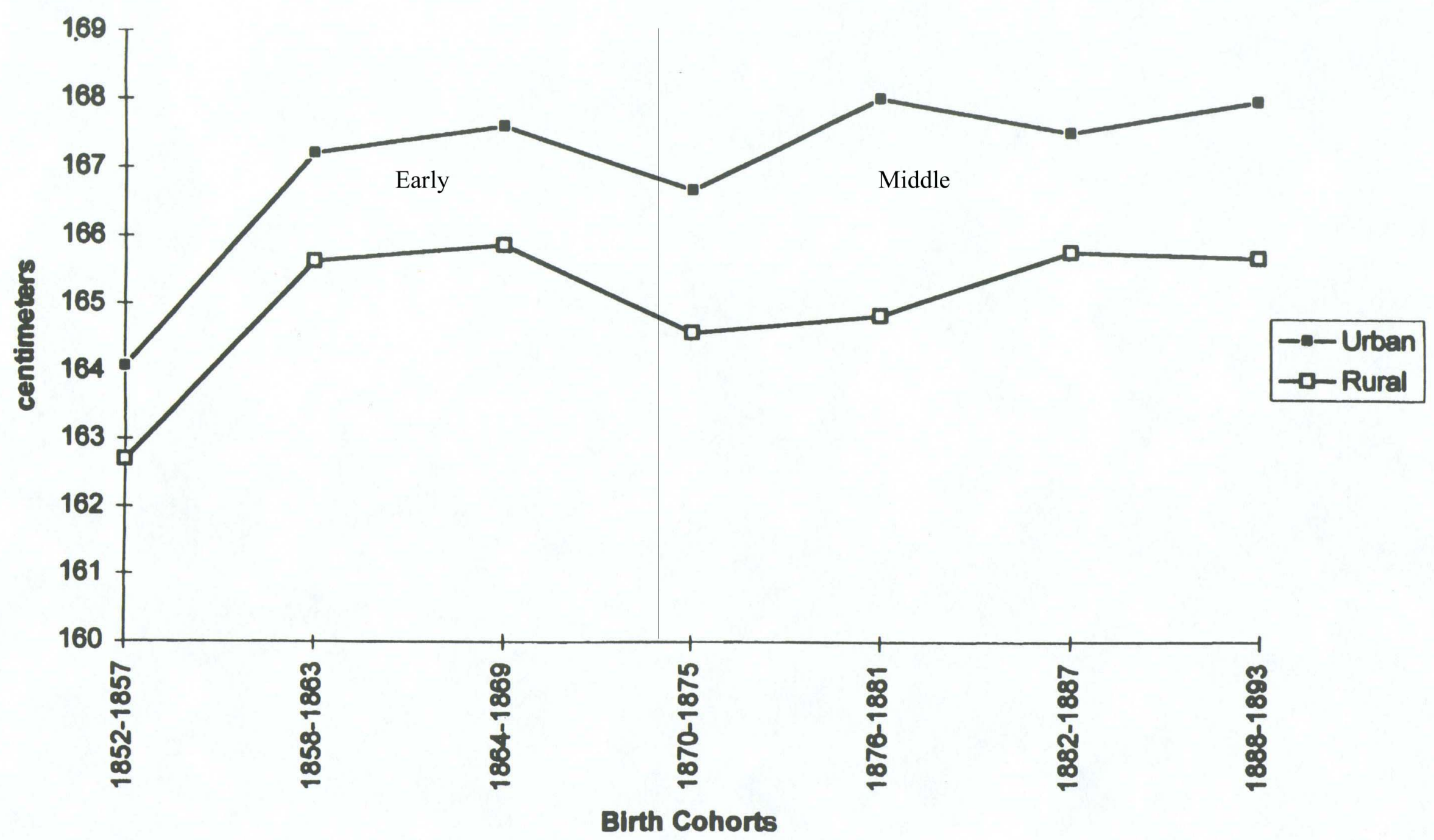

Source: Twarog (1997). 
Figure 10: Heights of Australian Recruits, Five-Year Moving Averages

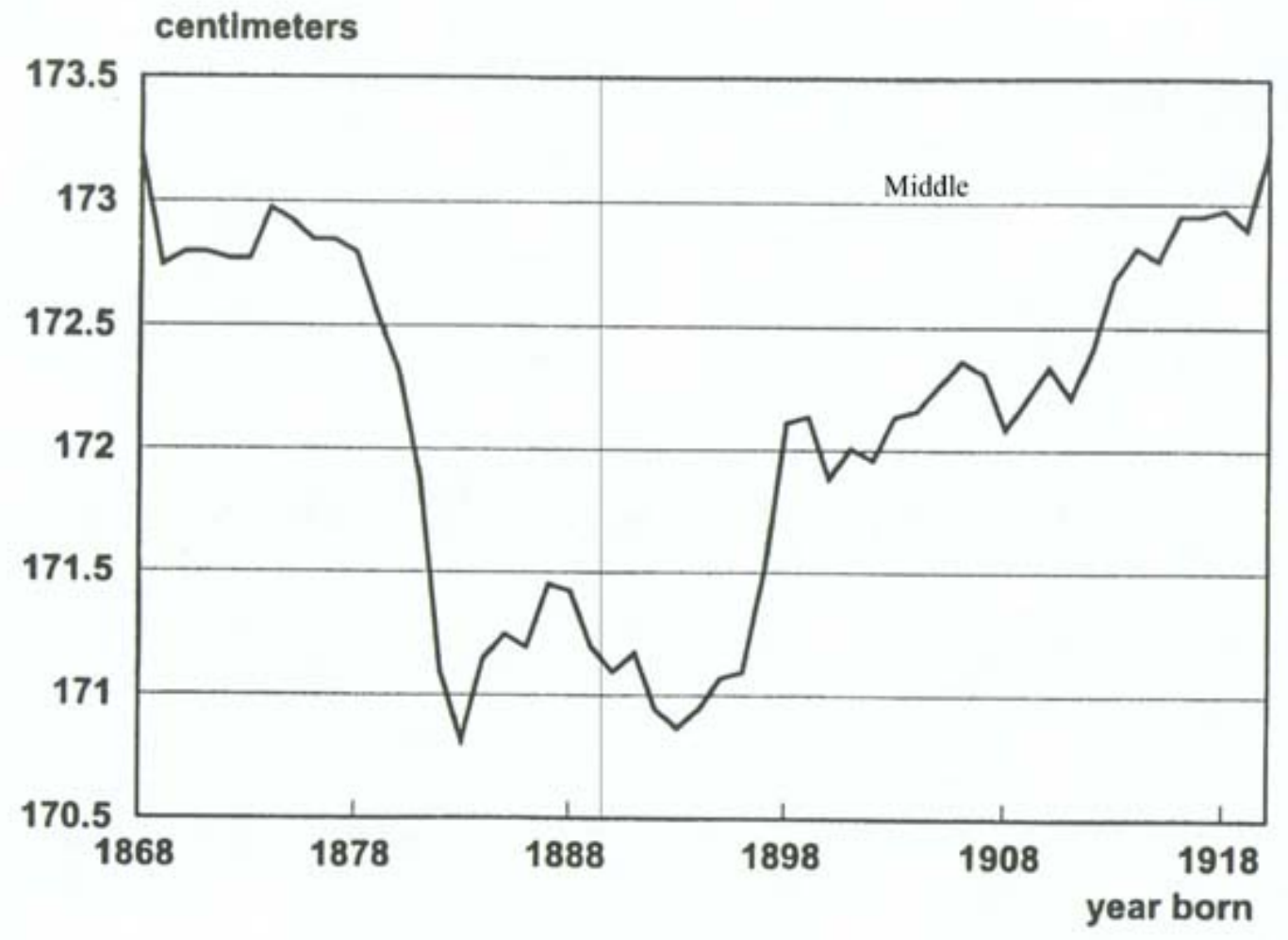

Source: Whitwell, de Souza and Nicholas (1997). 


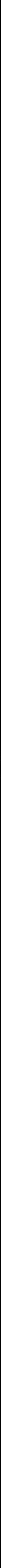

